American Journal of Biochemistry and Biotechnology 5 (2): 75-83, 2009

ISSN 1553-3468

(C) 2009 Science Publications

\title{
Characterization of the Adsorption of the Lead (II) by the Nonliving Biomass Spirogyra neglecta (Hasall) Kützing
}

\author{
Modher A. Hussain, Aishah Salleh and Pozi Milow \\ Phycology Laboratory, Institute of Biological Sciences, Faculty of Science, \\ University of Malaya, Kuala Lumpur 50603, Malaysia
}

\begin{abstract}
Problem statement: Conventional techniques for removing dissolved heavy metals are only practical and cost-effective when applied to high strength wastes with heavy metal ion concentrations greater than $100 \mathrm{ppm}$. The possibility of using a nonliving algal biomass to solve this problem was carried in this study. Lead (II) was used in this study because it had been reported to cause several disorders in human. Approach: The nonliving algal biomass was obtained from a filamentous green alga Spirogyra neglecta. The effects of initial concentration and contact time, $\mathrm{pH}$ and temperature on the biosorption of lead (II) by the nonliving algal biomass were studied. The equilibrium isotherms and kinetics were obtained from batch adsorption experiments. The surface characteristics of the nonliving algal biomass were examined using scanning electron microscope and Fourier Transformed Infrared. The maximum adsorption capacity of the nonliving algal biomass was also determined. Results: Maximum adsorption capacity of lead (II) was affected by its initial concentration. Adsorption capacity of lead (II) increased with the $\mathrm{pH}$ and temperature of lead (II) solution. Langmuir isothermic model fitted the equilibrium data better than the Freundlich isothermic model. The adsorption kinetics followed the pseudo-second-order kinetic model. The nonliving algal biomass exhibited acaves-like, uneven surface texture along with lot of irregular surface. FTIR analysis of the alga biomass revealed the presence of carboyl, amine and carboxyl group which were responsible for adsorption of lead (II). The maximum adsorption capacity $\left(\mathrm{q}_{\max }\right)$ of lead (II) by the nonliving biomass of Spirogyra neglecta was $132 \mathrm{mg} \mathrm{g}^{-1}$. Conclusion: The maximum adsorption capacity for lead (II) by the nonliving biomass of Spirogyra neglecta was higher than reported for other biosorbents. Therefore, it had a great potential for removing lead (II) from polluted water. Its use will also need to consider the various factors that affect biosorption process.
\end{abstract}

Key word: Adsorption, kinetics, Spirogyra neglecta, Langmuir model, second order model

\section{INTRODUCTION}

The presence of heavy metals in water systems has become a problem due to their harmful effects on human health even at low concentration in the environment. Lead (II) is among the most toxic heavy metal ion affecting the environment ${ }^{[1]}$. The current EPA and WHO drinking water standard for lead (II) is $0.05 \mathrm{mg} \mathrm{L}^{-1}$ and $10 \mu \mathrm{g} \mathrm{L}^{-1}$, respectively. Lead (II) accumulates mainly in bones, brain, kidney and muscles and may cause many serious disorders like anemia, kidney diseases, nervous disorders and sickness even death ${ }^{[2]}$. It is therefore, essential to remove lead (II) from wastewater before disposal. Conventional techniques for removing dissolved heavy metals such as chemical precipitation, carbon adsorption, ion exchange, evaporation and membrane processes ${ }^{[3]}$, are only practical and cost-effective when applied to high strength wastes with heavy metal ion concentrations greater than $100 \mathrm{ppm}^{[4]}$. Low strength heavy metal containing wastewaters generally cannot be treated successfully with such methods.

Adsorbent materials (biosorbents) derived from suitable biomass, on the other hand, has been shown to remove and recover of heavy metal ions from wastewater streams even at low concentrations. The phenomena of adsorption has been described in a wide range of living biomass like fungi ${ }^{[5]}$, bacteria ${ }^{[6,7]}$, yeast $^{[8]}, \operatorname{moss}^{[9]}$, aquatic plants ${ }^{[10]}$ and algae ${ }^{[11,12]}$. Algae is one of the most promising biosorbents ${ }^{[13]}$. Different algal species often had different sorption characteristics. The sorption characteristics have shown to be influenced by $\mathrm{pH}$, metal ion concentration, temperature, other metal ions ${ }^{[3]}$.

Corresponding Author: Modher A. Hussain, Phycology Laboratory, Institute of Biological Science, Faculty of Science, University of Malaya, Kuala Lumpur 50603, Malaysia Tel: +603-7967-4356 Fax: +603-7967-4178 
This study describes the adsorption of lead (II) by a nonliving biomass of a freshwater green alga identified as Spirogyra neglecta (Hasall) Kützing. Morphology of the nonliving algal biomass and its functional groups were also investigated.

\section{MATERIALS AND METHODS}

Chemical: All the reagents were of AR grade either from Germany or Starform-Malaysia. Stock solution of lead (II) was prepared using lead (II) nitrate(PlumbumII Nitrat, brand SYSTERM) in distilled water. Lead (II) solutions of different concentrations were obtained by diluting the stock solution. Standard solution of lead (II) $\left(250 \mathrm{mg} \mathrm{L}^{-1}\right)$ for atomic adsorption spectrophotometer was obtained from Germany. Standard acid and base solutions $(0.1 \mathrm{~N} \mathrm{HCl}$ and $0.1 \mathrm{~N}$ $\mathrm{NaOH}$ ) were used for $\mathrm{pH}$ adjustments.

\section{Equipments:}

- AAS atomic adsorption spectrophotometer Model AA-6200 (Shimadzu, Japan) at a wavelength of $283.3 \mathrm{~nm}$

- $\quad \mathrm{pH}$ meter (Eutch Instrument, Japan)

- FT-IR spectrometer Fourier transform infrared

- SEM scanning electron microscopy (JEOL 6400, Japan)

Preparation of biosorbent: Fresh sample of algal biomass of Spirogyra neglecta, was collected from a pond in Rimba Bukit Kiara in Kuala Lumpur, Malaysia. The sample was washed with distilled water five times to remove dirt (sand and epiphytes) The sample was subsequently kept on a filter paper to then dried in an oven at $45^{\circ} \mathrm{C}$ for $72 \mathrm{~h}$. The dried sample was then ground to powder using Igate stone pestle and mortar. The dried sample powder was then sieved to select the particles 300-425 $\mu \mathrm{m}$ using a standard testing sieve (Omron, UK). The powder of the wanted size (biosorbent), was then stored in plastic container at room temperature room and to used as the biosorbent and for subsequent analysis.

Effects of initial concentration and contact time: The adsorption of lead (II) ions on the dried biomass Spirogyra neglecta was investigated in batch adsorption equilibrium experiments. The experiment was performed by mixing $0.05 \mathrm{~g}$ of dried algae in $50 \mathrm{~mL}$ of the synthetic metal solutions. The $\mathrm{pH}$ of solution was kept without any $\mathrm{pH}$ treatment. The mixtures were mixed slowly with a rotary shaker at a rate of $150 \mathrm{rpm}$ for $60 \mathrm{~min}$ at temperature room. The solid biomass was separated from the liquid phase with membrane filter $0.45 \mu \mathrm{m}$, The concentration of lead (II) remaining in residual solution after a time lapse from the beginning of the experiment was determined by taking the residual solution absorbance on by atomic absorption spectrophotometer (AAS) Model AA-6200 (Shimadzu, Japan) at a wavelength of $283.3 \mathrm{~nm}$. (All measurements were carried out in an air/acetylene flame). The above was conducted on five different initial concentration of lead (II) i.e., 50, 100, 150, 200 and $250 \mathrm{mg} \mathrm{L}^{-1}$.

Effect of pH: The effect of solution $\mathrm{pH}$ on the lead (II) removal was examined by varying the initial $\mathrm{pH}$ of the solution from $\mathrm{pH} 3$ to $\mathrm{pH}$ 6. The $\mathrm{pH}$ was adjusted using $0.1 \mathrm{~N} \mathrm{HCl}$ and $0.1 \mathrm{~N}$ sodium hydroxide $(\mathrm{NaOH})$, magnetic stirrer was used to agitate the solution continuously and measurement using $\mathrm{pH}$ meter (EUTCH instrument, Japan). The $\mathrm{Pb}$ intial concentration was fixed at $150 \mathrm{mg} \mathrm{L}^{-1}$ with $0.05 \mathrm{~g}$ of the biosorbent agitation $1 \mathrm{~h}$, rotation speed $150 \mathrm{rpm}$ under temperature room.

Effect of temperature: The effect of temperature on the adsorption of lead (II) by the biosorbent was studied by setting the temperature of the shaking incubator. This study was carried out at three different temperatures $\left(40,50\right.$ and $\left.60^{\circ} \mathrm{C}\right)$ effect of temperature on the adsorption. The same initial concentration of lead (II) and $\mathrm{pH}$ was use in this study.

Determination of the adsorption capacity: The metal uptake can be calculated from:

$\mathrm{q}=\frac{\mathrm{V}\left(\mathrm{C}_{\mathrm{e}}-\mathrm{C}_{\mathrm{t}}\right)}{\mathrm{W}}$

Where:

$\mathrm{q}=$ The metal uptake (mg metal $\mathrm{g}^{-1}$ biomass)

$\mathrm{C}_{\mathrm{e}}=$ The initial metal concentrations in the solution (mg metal $\mathrm{L}^{-1}$ fluid)

$\mathrm{C}_{\mathrm{t}}=$ The metal concentrations in the solution (mg metal $\mathrm{L}^{-1}$ fluid) at time $\mathrm{t}$

$\mathrm{V}=$ The volume of solution

$\mathrm{W}=$ the dry weight $(\mathrm{g})$ of the added biosorbent

\section{Biosorption isothermic and kinetic models:}

Attempt was carried out to describe biosorption isothermics and kinetics of lead (II) by the nonliving biomass of Spirogyra neglecta. Langmuir and Freundlich isothermic models, Pseudo-first-orderkinetic and Pseudo-Second-order-kinetic models were used. Data used was obtained from section Effects of initial concentration and contact time. 
Am. J. Biochem. \& Biotech., 5 (2): 75-83, 2009

Langmuir isothermic model can be written in nonlinear form as:

$$
\frac{\mathrm{C}_{\mathrm{e}}}{\mathrm{q}_{\mathrm{e}}}=\frac{1}{\mathrm{q}_{\max } \mathrm{K}_{\mathrm{L}}}+\frac{1}{\mathrm{q}_{\max }} \mathrm{C}_{\mathrm{e}}
$$

Where:

$\mathrm{q}_{\max }=$ The monolayer adsorption capacity of the adsorbent $\left(\mathrm{mg} \mathrm{g}^{-1}\right)$ is the (maximum amount adsorbed)

$\mathrm{K}_{\mathrm{L}}=$ The Langmuir adsorption constant $\left(\mathrm{L} \mathrm{mg}^{-1}\right)$

$\mathrm{C}_{\mathrm{e}}=$ The equilibrium metal ion concentration in the solution $\left(\mathrm{mg} \mathrm{L}^{-1}\right)$

$\mathrm{q}_{\mathrm{e}}=$ The equilibrium metal ion concentration on the adsorbent $\left(\mathrm{mg} \mathrm{g}^{-1}\right)$

The solid phase equilibrium metal concentration which is the amount of metal adsorbed on the biomass surface in a batch system is calculated using the following mass balance equation:

$$
q=\frac{V\left(C_{e}+C_{t}\right)}{W}
$$

Where:

$\mathrm{q}=$ The metal uptake ( $\mathrm{mg}$ metal $\mathrm{g}^{-1}$ biomass)

$\mathrm{C}_{\mathrm{e}}=$ Initial metal concentrations in the solution (mg metal $\mathrm{L}^{-1}$ fluid)

$\mathrm{C}_{\mathrm{t}}=$ Final metal concentrations in the solution (mg metal $\mathrm{L}^{-1}$ fluid)

$\mathrm{V}=$ The volume of solution

$\mathrm{W}=$ The dry weight $(\mathrm{g})$ of the added biosorbent

The Freundlich isothermic model is written as:

$\ln \mathrm{q}_{\mathrm{e}}=\ln \mathrm{K}_{\mathrm{f}}+\frac{1}{2} \ln \mathrm{C}_{\mathrm{e}}$

Where:

$\mathrm{K}_{\mathrm{f}}=\mathrm{A}$ constant relating the adsorption capacity (Freundlich constants)

$1 / \mathrm{n}=$ An empirical parameter relating the adsorption intensity, (which varies with the heterogeneity of the material)

To describe the kinetics of the biosorption of lead (II) by the nonliving algal biomass, two models used: Pseudo-first-order-kinetic and Pseudo-Second-orderkinetic models. The pseudo first-order model is presented by the following equation ${ }^{[25]}$ :

$$
\log \left(\mathrm{q}_{\mathrm{e}}-\mathrm{q}_{\mathrm{t}}\right)=\log \mathrm{q}_{\mathrm{e}}-\frac{\mathrm{K}_{1}}{2303} \mathrm{t}
$$

Where:

$\mathrm{q}_{\mathrm{e}}$ and $\mathrm{q}_{\mathrm{t}}\left(\mathrm{mg} \mathrm{g}^{-1}\right)=$ The amounts of lead (II)adsorbed on the algal biomass at equilibrium and time in $\mathrm{mg} \mathrm{g}^{-1}$

$\mathrm{K}_{1} \quad=$ Constant of pseudo first-order adsorption

The pseudo second-order model is presented by the following equation ${ }^{[26]}$ :

$\frac{\mathrm{t}}{\mathrm{q}_{\mathrm{t}}}=\frac{1}{\mathrm{~K}_{2} \mathrm{q}_{\mathrm{e}}}+\frac{1}{\mathrm{q}_{\mathrm{e}}}$

Morphology of biosorbent: Scanning electron microscope examination of the biosorbent was done under SEM (JEOL 6400, Japan) to study the surface texture and morphology of the biosorbent. Sample of the biosorbent was prepared based on technique and procedure of Gabriel ${ }^{[14]}$.

Functional groups of biosorbent: Detection of functional groups in the biosorbent was done using the Fourier Transformed Infrared (FTIR). A sample of the biosorbent was mixed with $\mathrm{KBr}$ disc. The mixture was analyzed using FTIR in the range $370.0-4000.0 \mathrm{~cm}^{-1}$.

\section{RESULTS}

Effects of initial concentration and contact time: The adsorption of lead (II) increased with time and at certain point in time, it reached a constant value beyond which no more lead (II) was further removed from solution (Fig. 1). Maximum adsorption took place within the first $60 \mathrm{~min}$. The amount of lead (II) adsorbed at the equilibrium time was the maximum adsorption uptake by the adsorbent.

Effect of pH: The results of the adsorption lead (II) ions by the biosorbent are shown in Fig. 2. It shows that the process is a function of $\mathrm{pH}$. In this study, adsorption of lead (II) by the biosorbent increased until at pH 6.0.

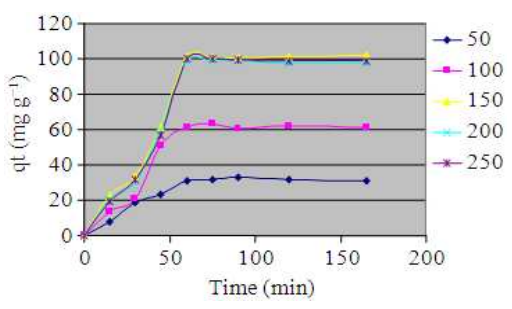

Fig. 1: Effect of initial concentration and contact time on adsorption of lead (II) by nonliving biomass Spirogyra neglecta 


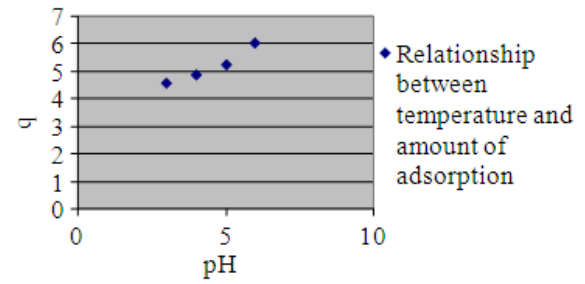

Fig. 2: Effect of $\mathrm{pH}$ on adsorption of lead (II) by nonliving biomass Spirogyra neglecta

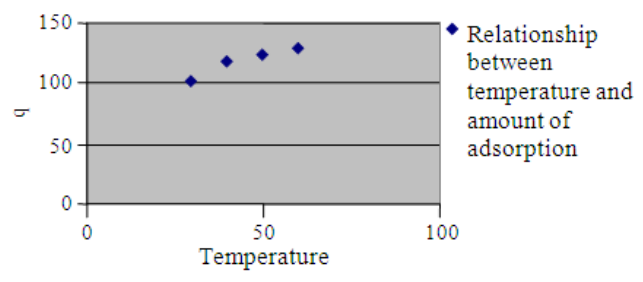

Fig. 3: Effect of temperature on adsorption of lead (II) by nonliving biomass Spirogyra neglecta

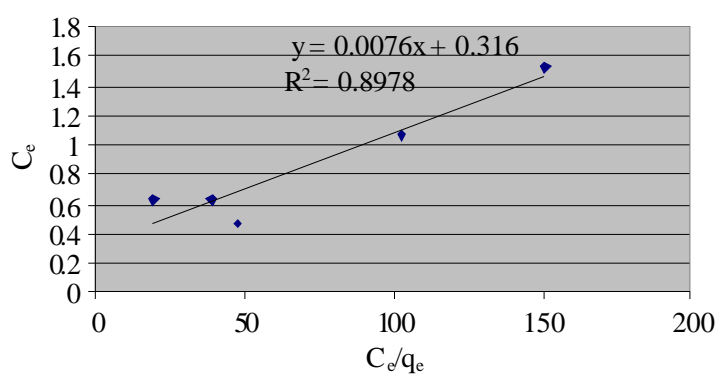

Fig. 4: Langmuir adsorption isotherm of lead (II) by the nonliving biomass of Spirogyra neglecta

Effect of temperature: Lead (II) adsorption uptake was found to increase with the increase in temperature (Fig. 3).

Determination of the adsorption capacity: The maximum adsorption capacity $\left(\mathrm{q}_{\max }\right)$ of lead (II) by the nonliving algal biomass was $132 \mathrm{mg} \mathrm{g}^{-1}$.

Biosorption isothermics and kinetics Figure 4 shows the plots of $\mathrm{C}_{\mathrm{e}}$ versus $\mathrm{C}_{\mathrm{e} / \mathrm{qe}}$ were drawn to calculate the values of $\mathrm{K}_{\mathrm{L}}$ which are shown in Table 1 .

The equilibrium relationship between metal adsorption and residual metal is typically hyperbolic ${ }^{[24]}$.

Figure 5 shows the plots of $1 / q_{\mathrm{e}}$ versus $1 / \mathrm{C}_{\mathrm{e}}$ were drawn to calculate the values of $\mathrm{K}_{\mathrm{F}}$ and $1 / \mathrm{n}$ which are shown in Table 1

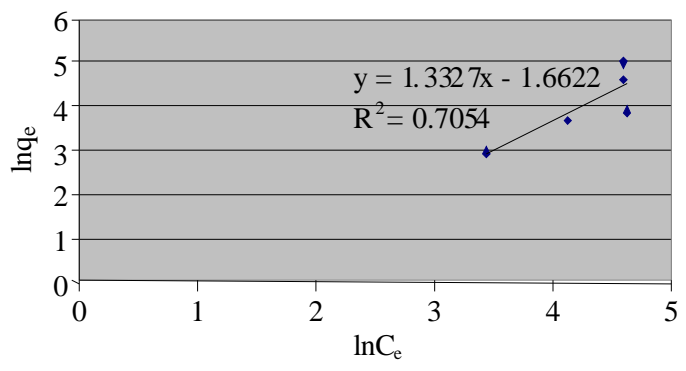

Fig. 5: Freundlich adsorption isotherm of lead (II) by the nonliving biomass of Spirogyra neglecta

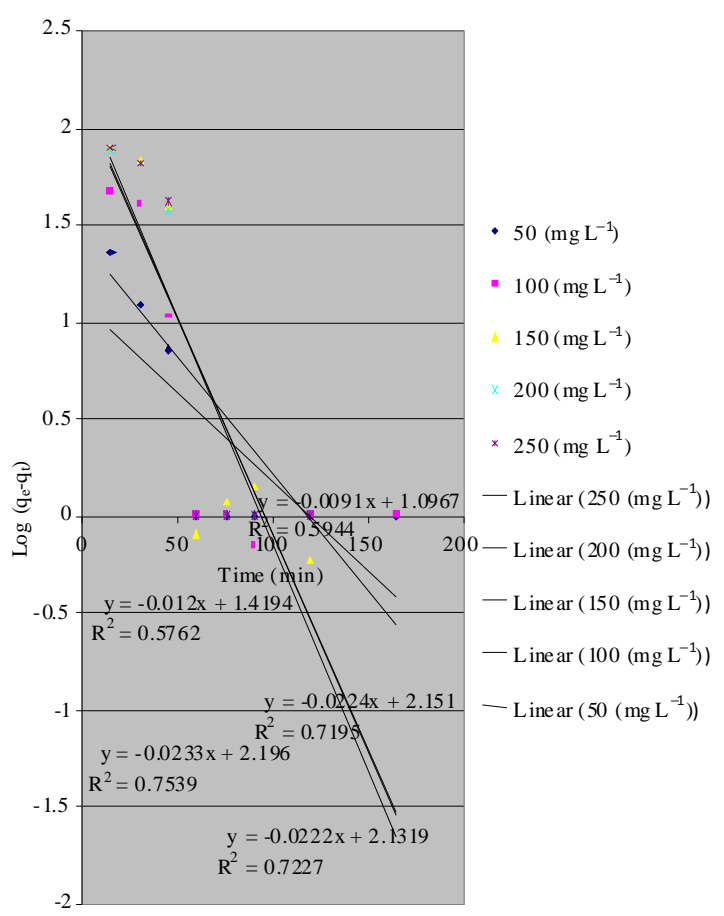

Fig. 6: Pseudo-first-order kinetic adsorption of lead (II) by the nonliving biomass of Spirogyra neglecta

Table 1: Langmuir and Freundlich constants

\begin{tabular}{lcc}
\hline Parameter & & \\
\hline Langmuir & Temperature & \\
$\mathrm{q}_{\max }\left(\mathrm{mg} \mathrm{g}^{-1}\right)$ & 132.0000 & $30 \pm 1$ \\
$\mathrm{k}_{\mathrm{L}}\left(\mathrm{L} \mathrm{mg}^{-1}\right)$ & 0.0230 & $30 \pm 1$ \\
$\mathrm{R}_{\mathrm{L}}{ }_{\text {Freundlich }}$ & 0.8978 & $30 \pm 1$ \\
$\mathrm{k}_{\mathrm{f}}\left(\mathrm{L} \mathrm{mg}^{-1}\right)$ & Temperature & \\
$\mathrm{n}$ & 0.1897 & $30 \pm 1$ \\
$\mathrm{R}_{\mathrm{f}}{ }^{2}$ & 0.7500 & $30 \pm 1$ \\
\hline
\end{tabular}

The plot $\ln \left(\mathrm{q}_{\mathrm{e}}-\mathrm{q}_{\mathrm{t}}\right)$ versus $\mathrm{t}$ as shown in Fig. 6 gives the slop of $\mathrm{K}_{1}$ and intercept of lnqe. The values of $\mathrm{K}_{1}$ and correlation, $R_{1}$ obtained from the Fig. 6 for adsorption of lead (II) on the biomass algal at $30^{\circ} \mathrm{C}$ are shown in Table 2. 
Table 2: First order kinetic model

\begin{tabular}{|c|c|c|c|c|}
\hline \multirow[b]{2}{*}{ Con $\mathrm{mg} \mathrm{L}^{-1}$} & \multicolumn{4}{|c|}{ First order kinetic model } \\
\hline & $\mathrm{q}_{\mathrm{e}}\left(\mathrm{mg} \mathrm{g}^{-1}\right) \exp$ & $\mathrm{q}_{\mathrm{el}}\left(\mathrm{mg} \mathrm{g}^{-1}\right)$ & $\mathrm{K}_{1}$ & $\mathrm{R}_{1}$ \\
\hline $50 \mathrm{mg} \mathrm{L}^{-1}$ & 30.8 & 12.49 & 0.021 & 0.5944 \\
\hline $100 \mathrm{mg} \mathrm{L}^{-1}$ & 61.4 & 26.26 & 0.028 & 0.5762 \\
\hline $150 \mathrm{mg} \mathrm{L}^{-1}$ & 102.1 & 157.03 & 0.054 & 0.7539 \\
\hline $200 \mathrm{mg} \mathrm{L}^{-1}$ & 97.2 & 135.49 & 0.051 & 0.7227 \\
\hline $250 \mathrm{mg} \mathrm{L}^{-1}$ & 98.8 & 141.58 & 0.052 & 0.7195 \\
\hline
\end{tabular}

Table 3: Second order kinetic model

\begin{tabular}{llll}
\hline & \multicolumn{2}{l}{ Second order kinetic model } & \\
& \multicolumn{1}{c}{$-\mathrm{K}_{2}$} & $\mathrm{R}_{2}$ \\
\hline Con. mg L & \multicolumn{1}{l}{$\mathrm{q}_{\mathrm{e} 2}$} & 1406.040 & 0.9108 \\
$100 \mathrm{mg} \mathrm{L}^{-1}$ & 40.650 & 2834.220 & 0.7535 \\
$150 \mathrm{mg} \mathrm{L}^{-1}$ & 95.230 & 12815.640 & 0.7648 \\
$200 \mathrm{mg} \mathrm{L}^{-1}$ & 166.660 & 14134.980 & 0.6867 \\
$250 \mathrm{mg} \mathrm{L}^{-1}$ & 166.660 & 16052.590 & 0.6875 \\
\hline
\end{tabular}

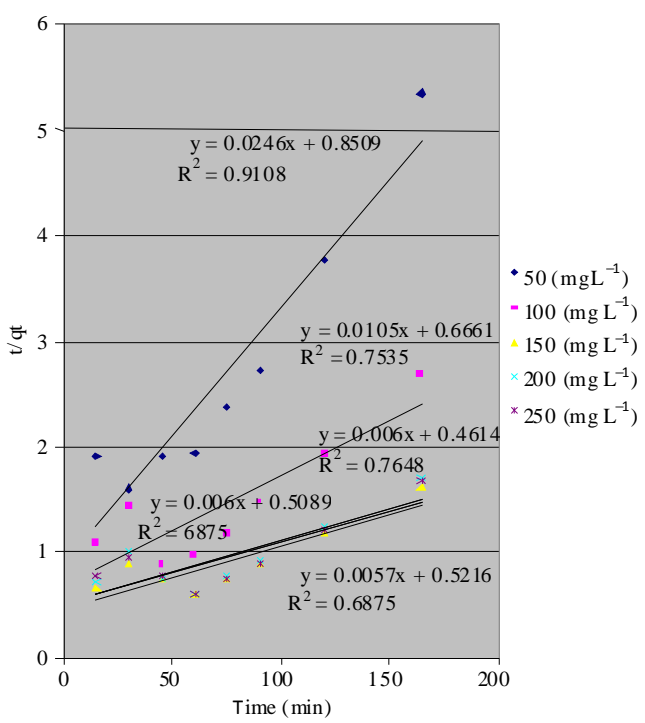

Fig. 7: Pseudo-second-order kinetic adsorption of lead (II) by the nonliving biomass of Spirogyra neglecta

Figure 7 showed the plots of t/qt versus $t$ at various initial concentrations. $K_{2}$ is the second order adsorption rate constants. The values of parameters $\mathrm{K}_{2}, \mathrm{q}_{\mathrm{e}}$ and correlation coefficients were shown in Table 3. The correlation coefficients obtained were greater from $R_{1}$.

Morphology of nonliving biomass of Spiroygra neglecta: Fig. 8a-d. It was evident from the micrographs that the biosorbent sample after-before adsorption. The algae exhibits acaves-like, uneven surface texture along with lot of irregular surface.

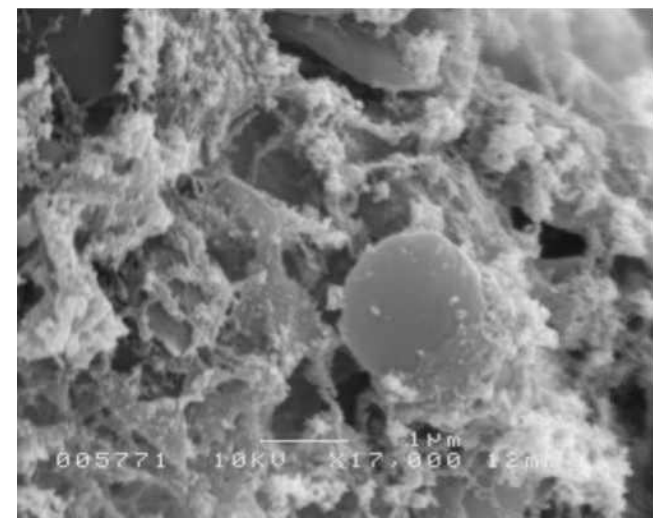

(a)

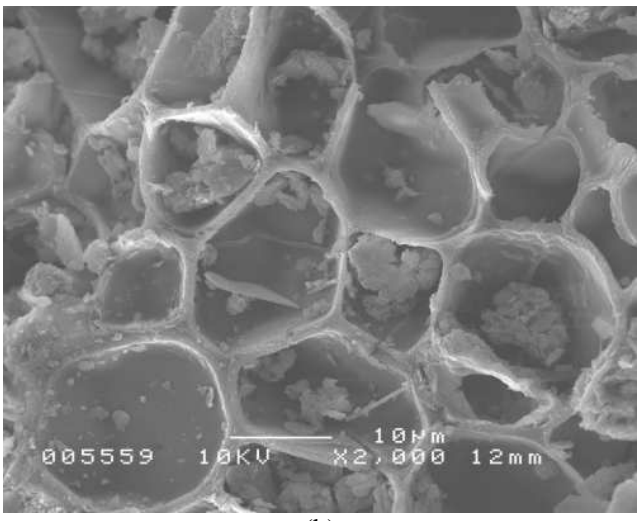

(b)

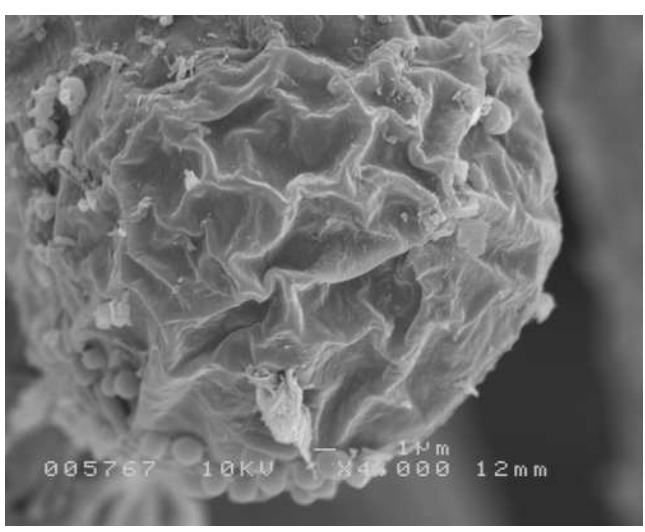

(c)

Fig. 8a-c: SEM image the biomass particles, with and without adsorbed metal

The Fourier Transform Infrared Spectrometer (FTIR) analysis: The result is shown in Fig. 9. It displayed a number of absorption peaks, indicating the complex nature of the biomass examined. The broad absorption peak around $2923 \mathrm{~cm}^{-1}$ is indicative of the existence of bonded carboxyl group (C-H). 
Am. J. Biochem. \& Biotech., 5 (2): 75-83, 2009

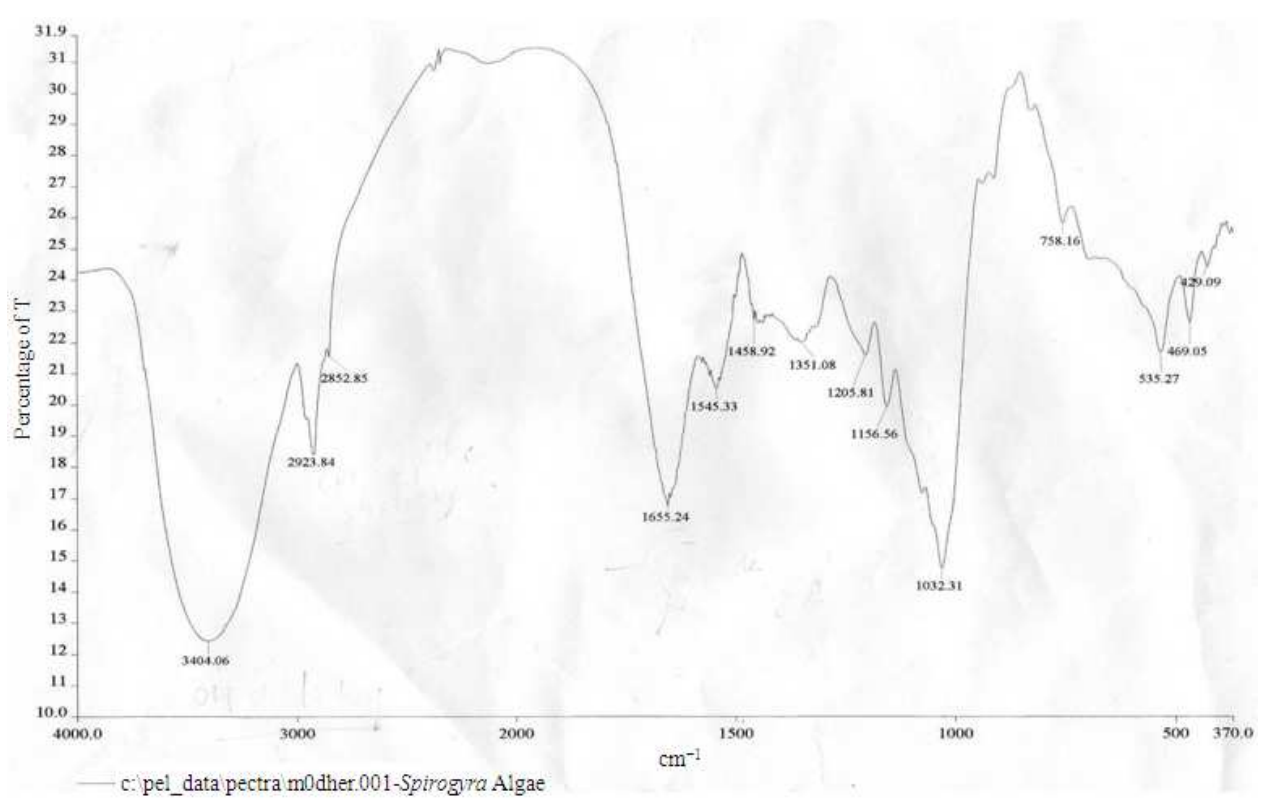

Fig. 9: Peaks for nonliving biomass of Spirogyra neglecta obtained from FTIR analysis

The peak observed at $1655 \mathrm{~cm}^{-1}$ can be assigned to the $(\mathrm{C}=\mathrm{O})$ carbonyl group. The peak observed at $3404.06 \mathrm{~cm}^{-1}$ can be assigned to the $(\mathrm{N}-\mathrm{H})$ amine group The peak observed at $1032 \mathrm{~cm}^{-1}$ can be assigned to the (C-O) carbonyl group.

\section{DISCUSSION}

Effects of initial concentration and contact time: The results revealed that the lead adsorption was fast at initial stage of the contact period and then became slower near the equilibrium. This phenomenon was due to the fact that a large number of vacant surface site were available for adsorption during the initial stage. Near the equilibrium the remaining vacant surface sites were difficult to be occupied due to repulsive forces between the solute molecules on the solid and bulk phase.

Effect of $\mathbf{p H}$ : These results suggest that the adsorption of metals on the biomass surface is controlled by ionic attraction. At low $\mathrm{pH}$ values, the inactivated cell surface becomes more positively charged, to reduce the attraction between metal ions and functional groups at the cell wall. In contrast, when the $\mathrm{pH}$ increases, the cell surface is more negatively charged and the process of retention is favored ${ }^{[16,17]}$. Until a maximum adsorption is reached around $\mathrm{pH} 6$. At $\mathrm{pH}$ higher than 6 , precipitation of insoluble metal hydroxides takes place restricting the true adsorption studies according to formula:

$$
\left(\mathrm{NO}_{3}\right)_{2}+\mathrm{NaOH} \rightarrow(\mathrm{OH})_{2} \downarrow+\mathrm{NaNO}_{3}
$$

lead (II) adsorption is maximized at pH6.0, a value which agrees with the results obtained by ${ }^{[18]}$ on their study of lead (II) by Pseudomonas putida. Seki et al. ${ }^{[21]}$ studied the function of $\mathrm{pH}$ on adsorption of lead (II) by Rhodobacter sphaeroides and reported that the maximum $\mathrm{pH}$ is around 6.0. The $\mathrm{pH}$ of metal solution has been shown to play an important role in the adsorption process ${ }^{[19]}$.

Effect of temperature: The adsorption reaction for the endothermic processes could be due to the increase in temperature increase the rate of diffusion of the adsorbate molecules across the external boundary layer and in the internal pores of the adsorbent particle, owning to the decrease in the viscosity of the solution ${ }^{[20]}$ also noted similar observations and they suggested that the increase in adsorption uptake with increase in temperature might be due to the possibility and in the total pore volume of the adsorbent, an increase of number of active sites for the adsorption as well as an increase in the mobility of the adsorbate molecules. Meena et al. ${ }^{[21]}$ reported that the increase in sorption with temperature may be attributed to either increase in the number of active surface sites available for sorption on the adsorbent or due to the decrease in 
Am. J. Biochem. \& Biotech., 5 (2): 75-83, 2009

the boundary layer thickness surroundings the sorbent, so that the mass transfer resistance of adsorbate in the boundary layer decreased. Temperature could influence the desorption and consequently the reversibility of the adsorption equilibrium also ${ }^{[22]}$. Increase in temperature will be followed by a decrease in adsorption capacity. This is because the rise in temperature damage active binding sites in the biomass ${ }^{[23]}$.

Langmuir and Freundlich adsorption isotherms: The correlation coefficients were extremely high, as shown in Table 1. These values of the correlation coefficients strongly support the fact that the lead-algal biomass adsorption data closely follow the Langmuir model compared to the Freundlich correlation coefficients. The high degree of correlation for the linearized Langmuir relationship suggests a single surface reaction with constant activation energy is the predominant sorption step and possibly the predominant rate-controlling step.

Pseudo-first-order-and Pseudo-Second-order kinetic model: The values of R1 relatively small for the pseudo-first-order are not satisfactory. Therefore, it has been concluded that the pseudo-second-order adsorption model is more suitable to describe the adsorption kinetics of lead (II) by algal biomass. These results imply that the adsorption system adheres to the pseudo second-order kinetics which further suggests that chemisorption is the rate-controlling $\operatorname{step}^{[36]}$. Therefore, the pseudo-second-order rate kinetic model best described the experimental data.

Characterization of the biosorbent:

Scanning electron microscope: These caves in biomass evidence the increase surface adsorption of lead.

The Fourier Transform Infrared Spectrometer (FTIR) analysis: The results indicated that the biomass has a variety of functional groups, such as carboxyl and amine and these groups are involved in almost all potential binding mechanisms. Depending on the $\mathrm{pH}$ value of the aqueous solution, these functional groups participate in met ion bindings ${ }^{[15]}$.

Comparison with other adsorbents: The monolayer adsorption capacity $\left(\mathrm{q}_{\max }\right)$ obtained in this study is compared with those obtained for other organisms. This is summarized in Table 4. The $\mathrm{q}_{\max }$ value obtained in this study is higher than the $\mathrm{q}_{\max }$ value of other organisms.
Table 4: Uptake capacities for lead (II) of various adsorbents at room temperature

\begin{tabular}{lll}
\hline Adsorbent & $\mathrm{q}_{\max }\left(\mathrm{mg} \mathrm{g}^{-1}\right)$ & Literature \\
\hline Chlamydomonas reinhardtii & 96.30 & {$[29]$} \\
Gelidium algae & 64.00 & {$[30]$} \\
Zoogloea ramigera & 82.80 & {$[31]$} \\
Pseudomonas aerogenosa & 23.00 & {$[7]$} \\
Cyclotella cryptic (diatom) & 26.28 & {$[32]$} \\
Bacillus sp. & 92.27 & {$[33]$} \\
Arthrobacter sp. & 130.00 & {$[13]$} \\
Phanerochaete chrysosporium & 134.00 & {$[28]$} \\
Rhizopus arrhizus & 76.40 & {$[34]$} \\
Arthrobacter sp. & 130.00 & {$[14]$} \\
Rhizopus arrhizus & 76.40 & {$[34]$} \\
Spirogyra neglecta & 132.00 & This study \\
\hline
\end{tabular}

\section{CONCLUSION}

This study shows that nonliving biomass of Spirogyra neglecta has the potential to remove heavy metals in polluted water. The adsorption for lead (II) was quick, as maximum removal took place $1 \mathrm{~h}$ of contact time. The maximum adsorption capacity for lead (II) is higher than reported for other biosorbents of lead (II) by the nonliving biomass of Spirogyra neglecta are characterized by the initial concentration of lead (II), temperature and $\mathrm{pH}$ of the solution, Adsorption isothermal models and functional group. These are useful in predicting the behavior of the biosobent under the different conditions so that it can be used effectively to remove heavy metals such as lead. Using nonliving biomass of Spirogyra neglecta has an advantage because the alga is one of most ubiquitous species of Spirogyra in Malaysia. However, the ability of the nonliving biomass of the alga to adsorb other metals will also need to be studied.

\section{ACKNOWLEDGMENT}

The researchers would like to thank the staff from Institute of Biological Science, Faculty of Science, University of Malaya. We will like to convey our thanks to University of Malaya for the financial assistance (grant No.PS176/2008A)

\section{REFERENCES}

1. Alloway, B.J. and D.C. Ayres, 1993. Chemical Principles of Environmental Pollution. Blackie Academic and Professional. 1st Edn., London, pp: 190-220.

2. Chua, L.W.H., K.H. Lam and S.P. Bi, 1999. Acomparative investigation on the adsorption of lead (II) by filamentous fungal biomass. Chemosphere, 39: 2723-2736. DOI: 10.1016/S0045-6535(99)00206-4 
3. Kojima, H. and K.Y. Lee, 2001. Photosynthetic Microorganisms in Environmental Biotechnology. 1st Edn., Springer-Verlag Hong Kong Ltd., Hong Kong, ISBN: 10: 9624301360, pp: 330.

4. Volesky, B., 1990. Adsorption of Heavy Metals. 1st Edn., CRC Press, Boca Raton, pp: 381.

5. Matheickal, J.T. and Q. Yu, 1997. Biosorption of lead(II) from aqueous solutions by Phellinus badius. Miner. Eng., 10: 947-957 DOI: 10.1016/S08926875(97)00076-9

6. Öztürk, A.T and A. Ayar, 2004. Biosorption of nickel(II) and copper(II) ions from aqueous solution by Streptomyces coelicolor A3(2). Colloids Surf. B. Biointerfaces, 34: 105-111. http://www.ncbi.nlm.nih.gov/pubmed/15261080

7. Chang, J., A.R. Law and C.C. Chang, 1997. Biosorption of lead, copper and cadmium by biomass of Pseudomonas aeruginosa PU21. Water Res., 31: 1651. DOI: 10.1016/S00431354(97)00008-0

8. Zhang, L.I., L.I. Zhao, Y. Yu and C. Chen, 1998. Removal of lead from aqueous solution by nonliving Rhizopus nigricans. Water Res., 32: 1437-1444. DOI: 10.1016/S0043-1354(97)00348-5

9. Low, K.S. and C.K. Lee, 1991. Cadmium uptake by the moss, Calymperes delessertii, Besch. Bioresour. $\quad$ Technol., $\quad 38$ : 1-6. http://cat.inist.fr/?aModele $=$ afficheN\&cpsidt $=5240$ 755

10. Schneider, I.A.H., J. Rubio, M. Misra and R.W. Smith, 1995. Eichhornia crassipes as biosorbent for heavy metal ions. Miner. Eng., 8: 979-988. DOI: 10.1016/0892-6875(95)00061-T

11. Yu, Q., J.T. Matheickal, P. Yin and P. Kaewsarn, 1999. Heavy metal uptake capacities of common marine macro algal biomass. Water Res., 1534: 1534-1537. DOI: 10.1016/S00431354(98)00363-7

12. Kaewsarn, P., 2002. Biosorption of copper(II) from aqueous solutions by pre-treated biomass of marine algae Padina sp. Chemosphere, 47: 1081-1085. DOI: 10.1016/S0045-6535(01)00324-1

13. Veglio, F. and F. Beolchini, 1997. Removal of metals by adsorption: A review. Hydrometallurgy, 44: 301-316.

http://direct.bl.uk/bld/PlaceOrder.do?UIN=021655 $340 \& \mathrm{ETOC}=\mathrm{RN} \&$ from $=$ searchengine

14. Ho, Y.S., 2004. Citation review of Lagergren kinetic rate equation on adsorption reactions. Scientometrics, $\quad 59$ : 171-177. http://www.springerlink.com/content/k08gm281k1 $4224 \mathrm{hj} /$
15. Demirbas, E., M. Kobya, E. Senturk and T. Ozkan, 2004. Adsorption kinetics for the removal of chromium (VI) from aqueous solutions on the activated carbons prepared from agricultural wastes. Water SA., 30: 533-540. http://www.wrc.org.za/archives/watersa\%20archiv e/2004/Oct-04/12.pdf

16. Gabriel, B.L., 1982. Biological Scanning Electron Microscopy. Illustrated Edn., Van Nostrand Reinhold, New York, ISBN: 0442229224, pp:186.

17. Volesky, B., 1987. Biosobents of metals recoverytrends. Biotechnology, 5: 96-101.

18. Volesky, B. and Z.R. Holan, 1995. Adsorption of heavy metals. Biotechnol. Prog., 11: 235-250.

19. Pardo, R., M. Herguedas, E. Barrado and M. Vega, 2003. Adsorption of cadmium, copper, lead (II) and zinc by inactive biomass of Pseudomonas putida. Anal. Bioanal. Chem., 376: 26-32. http://www.ncbi.nlm.nih.gov/pubmed/12734614

20. Seki, H., A. Suzuki and S.I. Mitsueda, 1998. Adsorption of heavy metal ions on Rhodobacter sphaeroides and Alcaligenes eutrophus H16. J. Colloid Interface Sci., 197: 185-190. DOI: 10.1006/jcis.1997.5284

21. Holan, Z.R., B. Volesky and I. Prasetyo, 1993. Adsorption of cadmium by biomass of marine algae. Biotechnol. Bioeng., 41: 819-825. DOI: 10.1002/bit.260410808

22. Wang, S. and Z. Zhu, 2007. Effects of acidic treatment of activated carbons on dye adsorption, Dyes Pigm., 75: 306-314. http://cat.inist.fr/?aModele $=$ afficheN\&cpsidt $=1878$ 5252

23. Meena, A.K., G.K. Mishra, P.K. Rai, C. Rajgopal and P.N. Nagar, 2005. Removal of heavy metal ions from aqueous solutions using carbon aerogel as an adsorbent. 122: 161-170. DOI: 10.1016/J.JHAZMAT.2005.03.024

24. Ozer, A., G. Akkaya and M. Turabik, 2006. Biosorption of Acid Blue 290 (AB 290) and Acid Blue 324 (AB 324) dyes on Spirogyra rhizopus. J. Hazard. $\quad$ Mater., 135: 355-364. http://www.ncbi.nlm.nih.gov/pubmed/16434139

25. Ozer, A. and D. Ozer, 2003. Comparative study of the biosorption of $\mathrm{Pb}(\mathrm{II}), \mathrm{Ni}(\mathrm{II})$ and $\mathrm{Cr}(\mathrm{VI})$ ions onto Saccharomyces cerevisae: Determination of biosorption heats. J. Hazard. Mater., 100: 219-229. http://www.ncbi.nlm.nih.gov/pubmed/12835024

26. Ho, Y.S. and G. McKay, 2000. The kinetics of sorption of divalent metal ions onto Sphagnum moss peat. Water Res., 34: 735-742. http://cat.inist.fr/?aModele $=$ afficheN\&cpsidt=1237 667 
27. Chojnacka, K., 2005. Biosorption of $\mathrm{Cr}$ (III) ions by eggshells. J. Hazard. Mater. B., 121: 167-173. http://www.ncbi.nlm.nih.gov/pubmed/15885418

28. Tuzun, I., G. Bayramoglu, E. Yalcin, G. Basaran, G. Celik and M.Y. Arica, 2005. Equilibrium and kinetic studies on biosorption of $\mathrm{Hg}(\mathrm{II}), \mathrm{Cd}(\mathrm{II})$ and $\mathrm{Pb}(\mathrm{II})$ ions onto microalgae Chlamydomonas reinhardtii. J. Environ. Manage., 77: 85-92. http://www.ncbi.nlm.nih.gov/pubmed/15993534

29. Vilar, V.J.P., C.M.S. Botelho and R.A.R. Boaventura, 2005. Influence of $\mathrm{pH}$, ionic strength and temperature on lead biosorption by Gelidium and agar extraction algal waste. Process Biochem., 40: 3267-3275.

http://cat.inist.fr/?aModele=afficheN\&cpsidt=1705 8421

30. Sag, Y., D. Ozer and T. Kutsal, 1995. A comparative study of the biosorption of lead (II) ions to $Z$. ramigera and $R$. arrhizus. Process Biochem., 30: 169-174.

http://cat.inist.fr/?aModele=afficheN\&cpsidt=3553 213
31. Gupta, V.K., A.K. Shrivastava and N. Jain, 2001. Biosorption of chromium (vi) from aqueous solutions by green algae Spirogyra species. Water Res., 35: 4079-4085. DOI: 10.1016/S00431354(01)00138-5

32. Tunali, S., A. Cubak and T. Akar, 2006. Removal of lead and copper ions from aqueous by bacterial strain isolated from soil. Chem. Eng. J., 115: 203-211. http://linkinghub.elsevier.com/retrieve/pii/S138589 4705004055

33. Iqbal, M. and R.G.J. Edyvean, 2004. Biosorption of lead, copper and zinc ions on loofa sponge immobilized biomass of Phanerochaete chrysosporium. Miner. Eng., 17: 217-223. DOI: 10.1016/j.mineng.2003.08.014

34. Sag, Y. and T. Kutsal, 1997. The simultaneous biosorption process of lead (II) and nickel (II) on Rhizopus arrhizus. Process Biochem., 32: 591-597. http://cat.inist.fr/?aModele $=$ afficheN\&cpsidt $=1080$ 7178 